23. Atkison PR. Weidman F:R, Bhaumick B, Bala RM (1980) Release of somatomedin-like activity by cultured WI-38 human thbroblasts. Fndocrinology $106: 20(0)(2-20) ! 2$

24. Clemmons DR. Underwood I.I: Van Wyk JJ 1981 Hormonal control of immunoreactive somatomedin production by cultured human fibroblasts. J (lin Invest 67:10--19

25. Adams S(). Nissley SP. Handwerger S. Rechler MM 1983 Ixevelopmental patterns of insulin-like factor $I$ and $I I$ synthesis and regulation in rat fibroblasts. Nature $3(0): 150-153$

26. ('opeland K(', Underweod I.F. Van Wyk JJ 1980) Induction of immunoreactive somatomedin-( in human serum by growth hormone: dose response relationships and effect on chromatographic profiles. J (lin Endocrinol Metab $50: 690-697$

27. Dean HJ, Kellet JC; Bala RM. (iuyda IJJ, Bhaumick B. Posner BI, Friesen 1H(; 1982 The effect of growth hormone treatment on somatomedin levels in growth hormone deficient chideren. J Clin bindocrinol Metahol 55.1167 117.3

28. Strain AJ, Hill I)J. Swenne I, Milner RIX) (1987) The regulation of DVA in human fetal hepatocytes by placental lactogen, growth hormone and insulin- like growth factor I/somatomedin-C. I (cll Physiol (in presso)

29. Richman RA. Benedict MR. Florini JR. Toly BA 1985 I formonal regulation of somatomedin secretion by fetal rat hepatocyes in primary culture. 1:ndocrinology $116: 180-188$

30. Clemmons J)R. Van Wyk Jj 1981 Somatomedin: Phosiological control and effects on cell proliferation. In: Baserga $R$ (ed) Tissuc (irowth factors Handbook of Experimental Pharmacology, Vol 57. Springer-Verlag. Berlin, op $16:-208$

31. Conover (A. Rosenfeld RF. Hintz R1. 1986 Hormonal control of the replication of human fetal fibroblasts: role of somatomedin-C Cinsulin-like growth factor I. J (cell Physiol 128:47-54

32. Adashi EY. Resnick ( $\mathrm{C}$. Swoboda ME. Van Wik JJ 1984 a nowel role for somatomedin- $C^{-}$in the cytodifferentiation of the ovarian gramulosa cell Endocrinology $115: 1227-1229$

33. Fwton DZZ. Florini JR 1981 Feffects of somatomedins and insulin on moblast differentiation in vitro, Dev Biol 86:31-39)

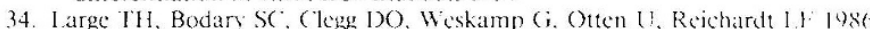
Nerve growth factor gene expression in the devetoping rat brain. Science $234: 352-355$

\title{
Announcement
}

\section{Nineteenth International Congress of Pediatrics}

The Congress will take place on July 23 to 28,1989 in Paris. France. Organizer: Professor Jean Frézal. Host: Societe Française de Pédiatrie. Sponsorship: International Pediatric Association. Languages: French. English. and Spanish.

For information comtact: PMV Congres, 130), rue de (lignancourt. 75018 Paris. France, Telex: 640 $847 \mathrm{~F}$. 